\title{
Challenges faced by Pakistani Women Social Entrepreneurs in War against Terrorism affected Areas
}

\author{
Nida Hussain*, Li Baoming \\ Business School of Zhengzhou University, China \\ Yunus Social Enterprise Center of Zhengzhou University \\ 100 Kexue Ave, Gaoxin District, Zhengzhou, Henan, China \\ Corresponding authors E-mail*: engr.nida@yahoo.com,LBMZZ@163.com
}

\begin{abstract}
In recent years, Pakistan controls on terrorism activities and move forward towards economic stability. For this stability and sustainability both genders are supposed to contribute in economic development and growth. According to study only $1 \%$ women social entrepreneurs out of $21 \%$ of male social entrepreneurs are operating in Pakistan. This shows the lowest rate of females operating in social business ventures inside Pakistan. This research is based on identifying the challenges faced by women Social Entrepreneurs from KPK and FATA (terrorism affected areas), Pakistan. Women in these areas have sturdy social and cultural influence. Therefore, it is important to identify what factors affecting the process of their operations and in executing their businesses in the local market. Moreover, about 88 to $90 \%$ of females started their businesses in social defiance. Hence, most of them work quietly for the first year in business. This research will address those challenging factors faced by women social entrepreneurs of KPK and FATA in daily life.
\end{abstract}

Keywords: Social Entrepreneur, Women Empowerment, Start-ups, Gender-gap.

DOI: $10.7176 / \mathrm{EJBM} / 12-18-17$

Publication date:June 30th 2020

\section{Introduction:}

After 9/11 attack, Pakistan was directly affected by the incidence of terrorism. Pakistan pay huge price against this war. The major impact of Terrorism was on reduction of economic growth. However, Pakistani Military forces fight against this situation (Shahzad, Zakaria, Rehman, Ahmed, \& Fida, 2016). They conducted various operations to overcome these issues. In this war, Federally Administered Tribal Areas (FATA) and Khyber Pakhtunkhwa (often abbreviated KP or KPK) related areas were directly affected. FATA and KPK regions are well known about tourism, agriculture, and traditional home based manufacturing industries of Pakistan (Alam, Akram, \& Iqbal, 2017; Ali, Mahsud, Khan, \& Naz, 2016). (Ahmed, 2013) stated terrorism brought direct and indirect impact on the economic growth and stability. Furthermore, it effects the foreign investments, increase in inflation and other factors.

During War against terrorism, women of KPK and FATA faced a lot of challenges (Browder, Aldrich, \& Bradley, 2019). They were supposed to migrate to cities and leave all their assets behind. All the migrants were supposed to stay at Internally Displaced Persons (IDPs) camp. Some of females try to make different communities to help their sister. During such situation, women came up with their business minds and start executing their business from inside and outside of these IDP camps. Among them some start working as women social entrepreneurs. The main idea of these women was to bring change in their life and later have positive impact on their society; when they will go back to their areas. Later, in 2018, government start sending IDP's back to their areas, these women took initiative to go back and work for their community.

Recently, Small Medium Enterprises (SME) are getting vital position in the economy of Pakistan. More than 78\% of jobs are providing through SME's. However, globally social entrepreneurs are considered as backbone for providing platform to unemployed, fresh graduates or skilled personals and highlight social causes/issues of underdeveloped areas. Both male and female got opportunities to work in the market. However, from evidence based studies, it is noted that women faces more challenges to operate in the market than men (Belwal, Belwal, \& Saidi, 2014).

It was reported that gap between male and female social entrepreneur is much less as compare to commercial businesses by Guardian Article. Significantly increase in number of women entrepreneurs has been observed across world (Bruni, Gherardi, \& Poggio, 2004). ). Moreover, their focus of doing business remains to small markets. Therefore, the trend of execution is relatively focused on increase by launch in the new markets (Ferreira \& Saridakis, 2017).

Terjesen, Bosma, \& Stam (2016) states that we cannot isolate women entrepreneurs from doing business. They have the right to perform their duties according to the business need without any social biasness (James, 2019, 
March 25). Traditional conservative gender bias still exists in Pakistani business market. Women doing business activities in the market is still considered odd (Browder et al., 2019; D. Report, 2019, October, 23). Unfortunately, women face more limitations in mobility, networking or sales.

The main objective of this study is to analyze the difficulties incurring in women social entrepreneurship of KPK and FATA. These women faced restrict social and cultural influence. This structure of social and cultural influence is inherited from generations. For instance, culturally and socially it may be disliked (or some extreme cases not acceptable) for women to own and operate businesses in the market place for their survival. This may be mainly due the conservative mind sets and biasness towards women. However, this trend would vary significantly in different regions and cultures. The specific objective is to suggest, the constitutional rights given to women are not properly exercised by government bodies. For instance, in policy making, regulatory bodies or any other institutional composition women entrepreneurs are not considered as a part of development process.

\section{Literature Review:}

Scholars and researchers believe that entrepreneurship can bring change in country economy. For instance, it can alleviate poverty by increasing revenue and growth (Power \& Reid, 2015). The idea of economic development was highlighted by (Kumar \& Usmani, 2016); it is mostly considered that entrepreneurship might have different dimensions to divert the concept of doing business in market. However, they concluded that a basic phenomenon is to generate profits and revenues (Ghaznavi, 2019; Lee Siew Kim \& Seow Ling, 2001; MCB University Press., 1988).

\subsection{Social Entrepreneur:}

In common phraseology, entrepreneur is linked with an active solution to market demand by providing product and services (Davidsson, 2015). In addition, entrepreneur is to enthused economic advancement by delivering innovation and creativity in their business (Beckmann, Huerta-Sanchez, \& Ngo, 2019; Ferreira \& Saridakis, 2017). Process of innovation is mostly focused on taking leverage by breaking ground records through new model development and by introducing new approaches (Halkias, Nwajiuba, Harkiolakis, \& Caracatsanis Sylva, 2011).

Social Entrepreneurs are defined as "Folks of society come up with innovative solutions, for those who are facing social trouble" (Yunus, 2020). ). Intelligent and determined individuals with standup team usually work persistently (Kumar \& Usmani, 2016). Their effective marketing strategy helps in tackling social matters and pressures (Baranik, Gorman, \& Wales, 2017). In addition, social entrepreneur with innovative ideas can effective address market based issues. Social entrepreneur is considered highly motivated and passionate about solutions to issues. They try to develop new strategies on a wide scale for improvement in society. Some scholar considered that social enterprises try to propose an innovative way to deal in business. Therefore, the purpose for the purpose of innovation is to bring positive change in society (Wu, Zhang, Zhang, \& Zou, 2020).

Hence mentioned above, social enterprises are supposed to address social issue. Likewise, operating in multiple disciplines may lead to boost in economic growth (Carruthers, McCarron, Bolan, Devine, \& McMahon-Beattie, 2014). The fundamental thrust for social enterprise is to envisage social value. Personal or shareholder profit generation is low priority.

\subsection{Women Social Entrepreneur of KPK and FATA:}

According to UN report published in 2016, as female literary rate increases by $75 \%$ which leads to decreases active women labor participation in agriculture, industry services and others by $67 \%$ to $75 \%$. Consequently, it decreases economic contribution of educated women (Baranik et al., 2017; Beckmann et al., 2019). Mostly, educated female prefer to secure good job position at organizations. Unfortunately, this trend leads to more unemployment in females (Breugst, Patzelt, \& Rathgeber, 2015). Recently, Pakistani economy is facing various challenges. For instance, 69\% unemployment ratio has been recorded among young population (both genders) (Ghaznavi, 2019).

In 2005, Entrepreneurship idea was introduce to Pakistani market and got more popularity in 2010 onward. Many young individuals came up with various innovative business ideas and started generating revenues (Hazlett, 2016; Horowitz Beth \& Saunders, 2019). However, numbers of female entrepreneurs were $1 \%$ female as compared to $22 \%$ of their male counterpart. This ratio shows that female entrepreneur participation in the market is closed to nonexistent (Howard, 2016, March 8; Lee, 1996; Power \& Reid, 2015).

However, later on vast change was observed in market about female entrepreneur appearance and assistance at national level as noted by (James, 2019, March 25). Steady growth has been observed in women entrepreneurs having desire to launched their own businesses and contribute to economy (Balachandra \& Dublish, 2019). In a similar fashion increase in number of female social entrepreneur are grown to bring optimistic change in society by launching their own businesses. These social entrepreneurs are targeting niche market for trading, creating 
working opportunities for other females and trying to bring investments for developments (Horowitz Beth \& Saunders, 2019).

Initially, women entrepreneurs were supposed to either operate from their home or must accompany by a male family member (West, 2011). However, this trend is changing. Females are executing their business in commercial way (Ghaznavi, 2019). In Pakistan, business environment for women are considered complex due to various factors. It is more complex for women from Tribal and FATA areas. Most women are not acknowledged about regulatory reforms, change in institutional agendas and latest market trends. In contrast to them male entrepreneur usually updates their knowledge (Power \& Reid, 2015). It is vital to know that root cause is discriminatory behavior of the local market towards women entrepreneurs. It is necessary to highlight the gender biases entrenched in typical Pakistani society which restricts women's mobility, exchanges of contacts, vigorous economic partaking and admittance towards business advancement in services.

According to UN Economic forum women entrepreneurs in Pakistan are considered as victim in business world. Women have less access to entrepreneurship opportunities and learning skills. In addition, they have no role in policy making (Howard, 2016, March 8; Wu et al., 2020). Further, they have noted that business literacy and practice among females are less in number than males. Beside this, those female who are already operating in market are facing various challenges in managing their businesses (Birley, Moss, \& Saunders, 1987).

\section{Challenging factors for Women social entrepreneurs of KPK and FATA:}

Pakistani women social entrepreneurs are engage with about $10 \%$ of active social causes. Only $4 \%$ to $5 \%$ are aware of financial instate for operating business. Beyond this, numbers of females are trapped in socio-cultural barriers, institutional barriers or lack of awareness that confine their entrepreneurial capabilities (Song, Elsner, Zhang, \& Berger, 2019). Including women social entrepreneurs from KPK and FATA, usually face more strict cultural influence among all. Below mentioned six norms are principally significant to be recognized or to be address to bring change. These are the challenging factors mostly faced by women social entrepreneurs during business executions.

$\begin{array}{ll}\text { 1. } & \text { Childcare or Household and social taboos } \\ \text { 2. } & \text { Social pressure about individual mobility } \\ \text { 3. } & \text { Gender biased inequality in society } \\ \text { 4. } & \text { Limited access to financial services } \\ \text { 5. } & \text { Lacking in technology and skills capabilities } \\ \text { 6. } & \text { Ability to handle failure }\end{array}$

\subsection{Childcare/Household and social taboos:}

Corporally women from KPK and FATA areas have strong bond in household and childcare. They used to take care of in-laws, kids, household chores etc. They are not easily allow to work outside of their houses. If, those who work outside are supposed to tackle households alone. Failing and doing so they are blamed and mocked for poor upbringing of their kids and their suitability for households maybe questioned. While traditional mindset believes women are supposed to take care of their houses solely responsible for the integrity of entire family. Usually women entrepreneurs manage houses in parallel to their businesses. They face more obstacles in operation as compare to men. Mostly, females are seen as doubtfully and inquired about their business. Society used to ask questions about their work. Therefore even female are able to manage all chores of house still society try to point out her success in negative way.

Occasionally, few women are lucky to have supportive family. Family support is considered as an essential part. Yet, women have to deal with middle man in their business operations. This middle man dealing is mostly opposing by phustoon culture. However, lack of knowledge of some women entrepreneurs and self-confidence middle man exploit profit margins. Earning imbalance also affects women entrepreneur's performance.

\subsection{Social pressure about individual mobility:}

In FATA and KPK region, solo mobility of female is generally considered anomalous. People see her with outlandish eyes in society. In addition, in some cases, those women who walk alone for achieving entrepreneurial goals, their character or morality is questioned. Social women entrepreneur face challenges in social networking for business promotions and marketing. Women entrepreneur usually uses support of husband, father or brother for initial entrepreneurial journey. In many cases, travelling alone from city to city or late night business meetings is restricted. Women from KPK and FATA areas are stickle to obey their day time working hours. 


\subsection{Gender biased inequality in society:}

Research advocates that a FATA and KPK women are fully capable to participate in economic growth. However, they are badly trapped in socio-cultural discrimination, traditions minatory statements and gender biased environment. The United Nations (U. Report) states dichotomy in Pakistan that it has insides and outsides. The reference of insides restricts women to liberty of homes and households. Likewise, dichotomy restricts women from getting education, skilled based education and trainings; employment to empowerment and social services. The reference of outside is realization about education in limited range, mobility, skill or employment opportunities at low wages. The ability of women social entrepreneurs are demoralize by restraining their mobility in market due to gender biased issues. During initial launch of their start-up in market, about $29 \%$ face marketing challenges, $25 \%$ face family pressure, $27 \%$ face government related policies and $30 \%$ face gender inequality issues.

\subsection{Limited access to financial services:}

Not all women social entrepreneurs or owners look for investment to start their business from scratch. Women social entrepreneurs can hoist the essential capital for their ventures by erudition about their needs and requests for more. Women social entrepreneurs grasp more in flexible attitude in gathering and raising the economic desires for their business growth. It is observed that women borrow less credit from banks, investors or economic institutes. Furthermore, they face issues in face financial problem due to obstruction of raw material, in-progress work and mostly no receipts in dealing with customers. The shortage of raw material, delay in delivering products and inefficient administration become death-knell of these women.

Due to less or non-adoption of the latest market trends of financial growth, women social entrepreneurs' countenance with expertise in obsolescence charge them high cost in production. We cannot overlook the financial conditions of women entrepreneurs. Recently, in Pakistan federal government appreciate the productivity and activeness of women entrepreneur, government brought improvement in the financial system.

In Pakistan, as per capita income of women is (PPP US\$ 1058). This is the lowest capita income in region. This makes it very difficult for women to finance their own businesses. Although in Islamic Shariah, women have same rights to own or buy a property. However, from a research study it was found that only $3 \%$ of plots in (model) villages or housing societies in cities own by women (Pakistan, 2019). Furthermore, women are restricted to access their collateral assets and consequently finance. Additionally, the main financial sources for women are their own personal savings, jewelry, property and family support. This research study was based on two hundred and forty women social entrepreneurs of KPK and FATA, who faced challenges at the early stages of their businesses. Specifically, they lacked in finance, awareness, administration, government policies. Also, during business development phase, tracking in technical and financial skills cause huge damage to women entrepreneurs. Lacking of bootstrap and seed capital knowledge among women social entrepreneurs is reason of initial failure. Female owned businesses are mostly lack in formal financial methods. Report identify the factor of reluctance, access bank, financial education are causes of a large amount of failure.

\subsection{Lacking in law, technology and skills capabilities:}

In Pakistan, legal issues and formalities are more complex for women to deal with them. Especially, rules and regulations related to business are more complicated. In past few decades corrupt practices are observed in some government business related bodies and basic amenities such as water and electricity supplies. More delays are incurred in different departments to get procedures done for obtaining permits. In addition, unreliable electric, water and gas supplies adversely affect the anticipation and trust of women social entrepreneurs.

Women are lacking in technology based knowledge and skills. Moreover, females in technical and engineering fields are not allowed to work freely as their male colleagues. Females in technology based businesses are very few due to working stereotype and due to the specific trends in education. For instance, there are certain fields such as medical or teaching considered more appropriate for girls. Besides, there are no proper technical education and training centers for women to acquire technical knowledge and hands on skills. In such situation women entrepreneurs are facing a lot of challenges and find it very difficult to concentrate on the glossy market trends for enterprise.

\subsection{Ability to handle failure:}

In a market, working with high male competitors is affray, it endure long for making position. A womanly social entrepreneur may have to face embryonic and manifest fright of the bigotry and containment from their families and closed relations. The person endeavor to envisage redundant worry and scuffle, if they find any weak, shy or moderate nature of women in Pakistan. If, enterprises cannot recognize the allowance threat which is absolutely vital to venture cause great damage. Therefore, skills development, technical knowledge or financial support 
reduces internal risks and challenges and increase business performance and proficiency.

Every entrepreneur has insecurities, uncertainties, risks and possibility of failure. Likewise, failure is a possible reality. Women entrepreneurs are advised not to reflect their insecurities during dreaming big about their venture. They should keep themselves highly motivated and increase their courage. They should stop self-doubting. It is very normal to have some challenges and one should try to bring significant improvement to their business.

\section{Methodology/Research methods}

\subsection{Procedure:}

Initially, research survey was conducted by using snowball technique. The study was based on 250 women social entrepreneurs operating in KPK and FATA. Various sectors of social entrepreneurs were categorized during research. During sample construction specific criteria was set; the operating age of business should be 3 years in market and having minimum 2 fulltime employees. The research aim was to determine the approach, dedication and allegiance of women to develop their businesses. The study also illustrated the obstruction, constraints and challenges with support and opportunities faced these women social entrepreneurs.

Exploratory research based on quantitative findings, data was collected through as many as thirty direct interviews conducted from women entrepreneurs. On the basis of those interviews a set of new recommendations and modification to the initial findings in the research study. Research aimed to find out the mean value of various variables through applying t-testing (a statistical approach) upon Childcare/Household and social taboos, social pressure about individual mobility; gender biased inequality in society; Limited access to financial services; Lacking in technology and skills capabilities; Ability to handle failure.

Initially, e-mails was drafted for direct interview and sent to executives/founder or co-founders. Out of 250 entrepreneurs, 240 participants fulfill the criteria; thirty were ready to give time and shared their experiences and also participate by filling questionnaires. SPSS version 20 was used to test the challenging factors faced by women social entrepreneurs.

\section{Data Collection:}

5.1 Age Group of Female Participation: About 240 women social entrepreneur took part in research study. Age group from 31 to 40 and 41 to 50 are highly active in social entrepreneurship, their percentage is from $27.19 \%$ to $34.32 \%$. These mature aged women were more active than younger aged women. This age gap indicated that young aged women are comparatively hesitant for embarking a career in business. Moreover, these young aged women are usually dependent upon their family members. Details mentioned in table 1.

Table 1: Participated age groups

\begin{tabular}{|l|l|l|}
\hline Age groups of the Participants & Frequency (f) & Percentage Value \\
\hline Below 20 & 9 & $8.02 \%$ \\
\hline 21 to 30 & 21 & $12.24 \%$ \\
\hline 31 to 40 & 66 & $27.19 \%$ \\
\hline 41 to 50 & 100 & $34.32 \%$ \\
\hline 50 above & 44 & $18.23 \%$ \\
\hline
\end{tabular}

5.2 Marital Status of Female Participants: In the below Table 2, highlights that married females have high rate of participation in social entrepreneurial activities $(57.3 \%)$ as compared to singles females $(28.1 \%)$. The participation is even lower for widows and divorces females $(6 \%$ to $8 \%)$. It should be noted that widow and divorced females also face similar market and social barriers as for as single or young female. According to these women, society is not ready to accept widow or divorced lady in business. They face more operational challenges in market as in the market as compared to married women who get more support from their families. 
Table 2: Marital Status of females

\begin{tabular}{|l|l|l|}
\hline Marital Status of Female Participants & Frequency (f) & Percentage Value \\
\hline Single & 65 & $28.10 \%$ \\
\hline Married & 115 & $57.30 \%$ \\
\hline Divorced & 20 & $6.30 \%$ \\
\hline Widow & 40 & $8.30 \%$ \\
\hline
\end{tabular}

5.3 Education Level of Participating Females: Table 3, states clearly about impact of education on business. These figures give us clear image that females having good educational background help them to move stably in market. About $61.8 \%$ of the females have completed their undergraduate education. They try to launch their final year projects as their business venture in the market. However, remain try to utilize their resources and experiences to start business.

Table 3: Educational Level

\begin{tabular}{|l|l|l|}
\hline Education Level & Frequency (f) & Percentage Value \\
\hline Secondary Level & 45 & $10.15 \%$ \\
\hline Higher Secondary Level & 55 & $18.05 \%$ \\
\hline Under graduation Level & 99 & $61.80 \%$ \\
\hline Graduation or Above Level & 41 & $10.00 \%$ \\
\hline
\end{tabular}

5.4 Business Categories of the Participating Females: 34.05\% of females are linked with textile industry. Due to Pakistan holds strong root in textile market. Females have easy access to fabric and other textile stuff to utilize their skills in creative market. While $4 \%$ and $5 \%$ of females are shopkeepers and traders which show that females avoid interacting with male customers. Hence, females are more comfortable in dealing with female customers than the male customers.

Table 4: Business Categories

\begin{tabular}{|l|l|l|}
\hline Business Categories & Frequency (f) & Percentage Value \\
\hline Technology Based & 29 & $9.85 \%$ \\
\hline Textile industry & 62 & $34.05 \%$ \\
\hline Architecture & 46 & $15.05 \%$ \\
\hline Food and Beverages & 55 & $23.05 \%$ \\
\hline Manufacturing Industry & 20 & $9 \%$ \\
\hline Trading & 15 & $5 \%$ \\
\hline Shopkeepers & 13 & $4 \%$ \\
\hline
\end{tabular}

5.5 Working Experience of Participating Females: About 32.23\% of females have above 7 year experience, which helped them in understanding business and execution. This can be count as best part for business owners for having working experience in market.

Table 5: Total number of working experience

\begin{tabular}{|l|l|l|}
\hline Total Number of working Experience & Frequency (f) & Percentage Value \\
\hline Up to 1 year & 31 & $10.55 \%$ \\
\hline 1 to 3 years & 65 & $26.13 \%$ \\
\hline 4 to 6 years & 70 & $13.09 \%$ \\
\hline 7 years above & 74 & $32.23 \%$ \\
\hline
\end{tabular}

5.6 Monthly Income of the Participating Females: Generating money is considered a greatest challenge in business. However, about $48 \%$ females are able to earn between $21 \mathrm{~K}$ to $30 \mathrm{~K}$ of monthly income. According to these females, they have very limited budget and this small amount of money is just enough for their survival. 
Table 6: Monthly Income

\begin{tabular}{|l|l|l|}
\hline Monthly Income & Frequency (f) & Percentage Value \\
\hline Below $10 \mathrm{~K}$ & 19 & $15.55 \%$ \\
\hline $11 \mathrm{~K}$ to $20 \mathrm{~K}$ & 22 & $23.99 \%$ \\
\hline $21 \mathrm{~K}$ to $30 \mathrm{~K}$ & 42 & $48 \%$ \\
\hline $31 \mathrm{~K}$ to $40 \mathrm{~K}$ & 10 & $8.35 \%$ \\
\hline $40 \mathrm{~K}$ above & 7 & $4.11 \%$ \\
\hline
\end{tabular}

5.7 Family living style of Participating Females: Family living style holds strong impact on females business running manners. It can clearly observe in table 7 , that $48.9 \%$ of separately living females have strong hold on their business and they are more focused on their working routines. Besides, they are able to execute their house chore easily.

Table 7: Family Living style

\begin{tabular}{|l|l|l|}
\hline Family Living style & Frequency (f) & Percentage Value \\
\hline Separately Living & 109 & $48.90 \%$ \\
\hline Living in Joint family & 81 & $29.10 \%$ \\
\hline Extended & 40 & $14 \%$ \\
\hline Others & 10 & $8 \%$ \\
\hline
\end{tabular}

5.8 Number of children of Participating Females: Females are considered as nuclear of their houses and they are supposed to invest in brought up of their children. Mostly, females claim their child's are their strength and they working or owning their business for just for proper education and future development of children. Following table 8 shows the total numbers of kids these females has.

Table 8: Total numbers of children

\begin{tabular}{|l|l|l|}
\hline Total Number of Children & Frequency (f) & Percentage Value \\
\hline None & 75 & $36.79 \%$ \\
\hline 1 to 2 & 64 & $22.10 \%$ \\
\hline 3 to 4 & 69 & $22.12 \%$ \\
\hline 5 above & 32 & $18.99 \%$ \\
\hline
\end{tabular}

5.9 T- testing upon challenging factors: As challenging factors are clearly mentioned above. $\mathrm{T}$-testing will be run to access the values of these challenging factors as variable. As T-testing is one of inferential statistical type. This help to determine the normal distribution and they freedom for significant value. Following table 9 describes the sample size, standard mean, standard deviations and error.

Table 9: descriptive statistical Values

\begin{tabular}{|l|l|l|l|l|}
\hline & $\mathrm{N}$ & Standard Mean & Standard Deviation & Mean Error \\
\hline Childcare/Household and social taboos & 240 & 6.11 & 1.418 & 0.001 \\
\hline Gender biased inequality in society & 240 & 6.65 & 0.919 & 0.041 \\
\hline Social pressure about individual mobility & 240 & 6.31 & 0.982 & 0.081 \\
\hline Limited access to financial services & 240 & 6.28 & 0.71 & 0.046 \\
\hline Lacking in technology and skills capabilities & 240 & 6.60 & & 0.021 \\
\hline Ability to handle failure & & & 1.11 & 0.011 \\
\hline
\end{tabular}

Above, Table 9 shows the mean value of all variables. However, ability to handle failure and gender biased inequality in society is observed high mean values then rest of variable factors. 
Table 10: T-Testing (One-Sampling Test)

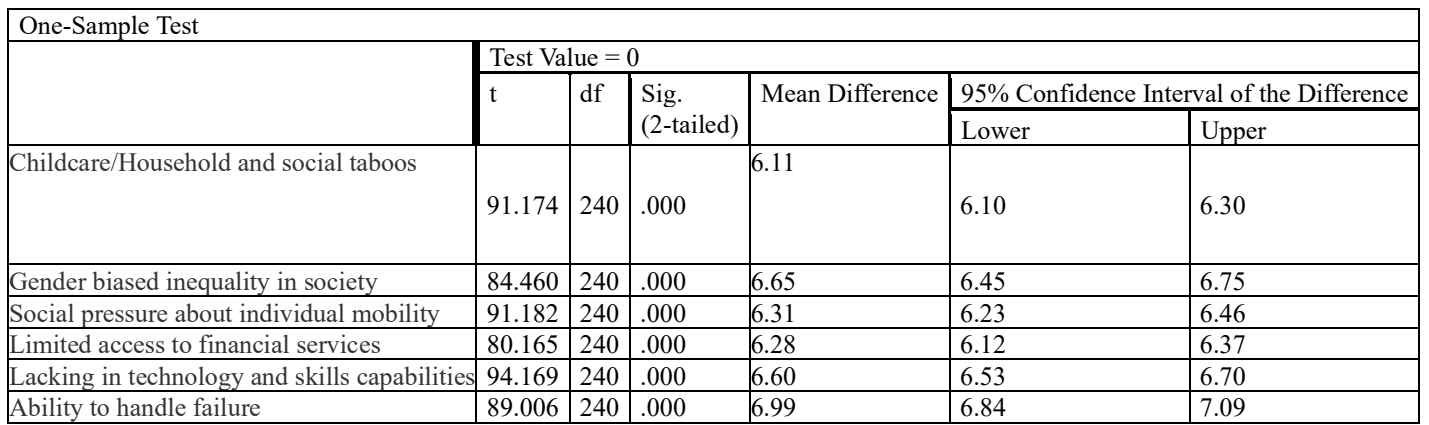

5.10 Result: In above table 10, the Sig. probability value is equals to .000 which is less then Sig. means value of 0.05 . Hence, it clearly describes through t-testing for childcare or households, social taboos, gender biased inequality in society, social pressure about individual mobility, limited access to financial services, lacking in technology and skill capabilities and ability to handle failures has strong influence on the growth and development of women social entrepreneurs in KPK and FATA regions of Pakistan. These are one of the factors that directly impact on the performance of KPK and FATA women social entrepreneurs. Government and social activists needs to address this issues and proposed solutions to the problem. Specially, government can help these women in regulation, policy making and financing. Moreover, public awareness and education is needed to bring change in thinking of society.

\section{Conclusion(s)}

The reason behind this research was to highlight those issues and challenges faced by women social entrepreneurs in KPK and FATA. Recently, economic development, unemployment and instability are major concerns for the nation. In such situation, Pakistani female entrepreneurs (as well as male entrepreneurs) can help in eliminating inequality, unemployment and develop plans for sustainable economic growth of Pakistan.

Government is working hard to bring peace and prosperity to these terror affected areas. These women face hardships during terrorism. These women are very strong emotionally and mentally. Therefore, social entrepreneurial activities can bring more optimistic change in the development of these war affected areas. As the number of youngest from these areas are high. So, entrepreneurial activities can bring innovative change in these areas.

Instead of creating job seeking techniques, institutes should create platforms for the awareness and significance of entrepreneurship. Awareness programs should focus on skills development, technical education and most important to deal with latest technique for financial stability. Government needs to concentrate on the empowerment of women by providing equal trading and business opportunities in local and international market. The dilemma of Pakistani women social entrepreneurs in these areas is that they are discouraged and depressed through tradition, social, cultural taboos. As a part of society, we have to promote and help those females who take risk in their lives and stand for change in society.

Funding: Fund support: 2019 high end foreign experts program of the Ministry of science and technology of the People's Republic of China (G20190226010).

\section{Acknowledgment(s)}

A large number of people have made possible and contributed to my research work. It is a pleasure to convey my gratitude to them all in my humble acknowledgment. Foremost, I would like to give my heartfelt thanks to my supervisor Professor Li Baoming, for his encouragement, guidance and support from the initial to the final phase of this research and for giving me the experience of conducting research throughout the work. Thanks, to Women Entrepreneur Association to help me to connect with Social Entrepreneurs from KPK and FATA region. Without their cooperation I was not able to gather data related to research work. Last but not the least, I wish to express my gratitude to my beloved family, specially my parents and friends for their sincere prayers, support and continuous motivation during the entire length of my course and research work. 


\section{References}

Ahmed, A. D. (2013). Effects of financial liberalization on financial market development and economic performance of the SSA region: An empirical assessment. Economic Modelling, 30, 261-273. doi:10.1016/j.econmod.2012.09.019

Alam, H. M., Akram, M., \& Iqbal, Z. (2017). The terrorism and foreign direct investment: The case of Pakistan. Journal of Research Society of Pakistan, 54(1), 71-77.

Ali, M. A., Mahsud, N. K., Khan, W., \& Naz, A. (2016). War against terrorism and its impact on children's academic performance in district Swat Khyber Pakhtunkhwa Pakistan. Journal Of Management Info, $9(1), 12-20$.

Balachandra, L., \& Dublish, P. (2019). Women for Women in Entrepreneurship: Understanding the Role of Other Women for Women's Entrepreneurship. In L. C. Victoria (Ed.), Go-to-Market Strategies for Women Entrepreneurs (pp. 239-260): Emerald Publishing Limited.

Baranik, L. E., Gorman, B., \& Wales, W. J. (2017). What Makes Muslim Women Entrepreneurs Successful? A Field Study Examining Religiosity and Social Capital in Tunisia. Sex Roles, 78(3-4), 208-219. doi:10.1007/s11199-017-0790-7

Beckmann, K. S., Huerta-Sanchez, D., \& Ngo, T. N. (2019). REIT industry liquidity, valuation, and ownership reactions to ETF inceptions. Applied Economics, 1-17. doi:10.1080/00036846.2019.1708859

Belwal, S., Belwal, R., \& Saidi, F. A. (2014). Characteristics, Motivations, and Challenges of Women Entrepreneurs in Oman's Al-Dhahira Region. Journal of Middle East Women's Studies, 10(2), 135-151. doi:10.2979/jmiddeastwomstud.10.2.135

Birley, S., Moss, C., \& Saunders, P. (1987). Do Women Entrepreneurs Require Different Training? American Journal of Small Business, 12(1), 27-36. doi:10.1177/104225878701200102

Breugst, N., Patzelt, H., \& Rathgeber, P. (2015). How should we divide the pie? Equity distribution and its impact on entrepreneurial teams. Journal of Business Venturing, 30(1), 66-94. doi:10.1016/j.jbusvent.2014.07.006

Browder, R. E., Aldrich, H. E., \& Bradley, S. W. (2019). The emergence of the maker movement: Implications for entrepreneurship research. Journal of Business Venturing, 34(3), 459-476. doi:10.1016/j.jbusvent.2019.01.005

Bruni, A., Gherardi, S., \& Poggio, B. (2004). Entrepreneur-mentality, gender and the study of women entrepreneurs. Journal of Organizational Change Management, 17(3), 256-268. doi:10.1108/09534810410538315

Carruthers, C., McCarron, B., Bolan, P., Devine, A., \& McMahon-Beattie, U. (2014). Listening and Learning: Reflections on the use of Audio Feedback. An Excellence in Teaching and Learning Note. Business and Management Education in HE, 1(1), 4-11. doi:10.11120/bmhe.2013.00001

Davidsson, P. (2015). Entrepreneurial opportunities and the entrepreneurship nexus: A re-conceptualization. Journal of Business Venturing, 30(5), 674-695. doi:10.1016/j.jbusvent.2015.01.002

Ferreira, P., \& Saridakis, G. (2017). Firm Shutdown During the Financial and the Sovereign Debt Crises: Empirical Evidence from Portugal. International Journal of the Economics of Business, 24(2), 153-179. doi:10.1080/13571516.2017.1309105

Ghaznavi, U. (2019). Women Entrepreneurs in Pakistan Retrieved from http://thenestio.com/womenentrepreneur-report.pdf

Halkias, D., Nwajiuba, C., Harkiolakis, N., \& Caracatsanis Sylva, M. (2011). Challenges facing women entrepreneurs in Nigeria. Management Research Review, 34(2), 221-235. doi:10.1108/01409171111102821

Hazlett, T. W. (2016). Understanding the Disruptive Innovation Wrought by Computers and the Internet: A Review. International Journal of the Economics of Business, 23(3), 391-408. doi:10.1080/13571516.2016.1220472

Horowitz Beth, S., \& Saunders, V. (2019). SheEO: How Reinventing the Ecosystem for Female Entrepreneurs Can Help Change the World. In L. C. Victoria (Ed.), Go-to-Market Strategies for Women Entrepreneurs (pp. 219-230): Emerald Publishing Limited.

Howard, E. (2016, March 8). 'One of the barriers for women entrepreneurs is a lack of role models'. The Guardian News. Retrieved from https://www.theguardian.com/small-businessnetwork/2016/mar/08/one-of-the-barriers-for-women-entrepreneurs-is-a-lack-of-role-models

James, A. G. a. A. d. R. S. (2019, March 25). We need more female entrepreneurs. Universities can help create them. The Guardian. Retrieved from https://www.theguardian.com/education/2019/mar/25/we-needmore-female-entrepreneurs-universities-can-help-create-them

Kumar, R., \& Usmani, A. (2016). A Study on the Perception of Women Employees Regarding their Empowerment in Travel Industry. Splint International Journal of Professionals, 3(5), 43. 
Lee, J. (1996). The motivation of women entrepreneurs in Singapore. Women in Management Review, 11(2), 1829. doi:10.1108/09649429610112574

Lee Siew Kim, J., \& Seow Ling, C. (2001). Work-family conflict of women entrepreneurs in Singapore. Women in Management Review, 16(5), 204-221. doi:10.1108/09649420110395692

MCB University Press. (1988). Journal of organizational change management. In. Bradford, England: MCB University Press.

Pakistan, U. (2019). UNICEF Annual Report. Retrieved from https://www.unicef.org/pakistan/media/2021/file/Annual\%20Report\%202018\%20Revised\%20Final.pdf

Power, B., \& Reid, G. C. (2015). Performance and Strategy: Simultaneous Equations Analysis of Long-lived Firms. International Journal of the Economics of Business, 22(3), 345-377. doi:10.1080/13571516.2015.1051751

Report, D. (2019, October, 23). Women drive social business growth in Pakistan: global poll. International The News. Retrieved from https://www.thenews.com.pk/print/544909-women-drive-social-business-growthin-pakistan-global-poll

Report, U. UN World Economic Forum. Retrieved from https://www.weforum.org/organizations/united-nations

Shahzad, S. J. H., Zakaria, M., Rehman, M. U., Ahmed, T., \& Fida, B. A. (2016). Relationship between FDI, terrorism and economic growth in Pakistan: Pre and post 9/11 analysis. Social Indicators Research, 127(1), 179-194.

Song, Y., Elsner, W., Zhang, Z., \& Berger, R. (2019). Collaborative innovation and policy support: the emergence of trilateral networks. Applied Economics, 1-18. doi:10.1080/00036846.2019.1708254

Terjesen, S., Bosma, N., \& Stam, E. (2016). Advancing Public Policy for High-Growth, Female, and Social Entrepreneurs. Public Administration Review, 76(2), 230-239. doi:10.1111/puar.12472

West, M. (2011). Developing high quality data models. Burlington, MA: Morgan Kaufmann.

Wu, J., Zhang, J., Zhang, S., \& Zou, L. (2020). The economic policy uncertainty and firm investment in Australia. Applied Economics, 1-25. doi:10.1080/00036846.2019.1710454

Yunus, N. (2020). Commonalities across commercial real estate indexes. Applied Economics, 1-17. doi: $10.1080 / 00036846.2019 .1708256$ 